\title{
thebmj
}

\section{Are the new MHRA follow-up recommendations for patients with metal-on-metal hip replacements justified?}

\begin{tabular}{|r|l|}
\hline Journal: & BMJ \\
\hline Manuscript ID & BMJ.2017.040593.R1 \\
\hline Article Type: & Analysis \\
\hline BMJ Journal: & BMJ \\
\hline Date Submitted by the Author: & n/a \\
\hline Complete List of Authors: & $\begin{array}{l}\text { Matharu, Gulraj; University of Oxford Nuffield Department of Orthopaedics } \\
\text { Rheumatology and Musculoskeletal Sciences, } \\
\text { Judge, Andrew; University of Oxford, NIHR Musculoskeletal Biomedical } \\
\text { Research Unit; University of Southampton, MRC Lifecourse Epidemiology } \\
\text { Unit } \\
\text { Pandit, Hermant; Nuffield Orthopaedic Centre, Nuffield Department of } \\
\text { Orthopaedics, Rheumatology and Musculoskeletal Sciences } \\
\text { Murray, David; University of Oxford, NDORMS; Oxford University Hospitals } \\
\text { NHS Foundation Trust, Nuffield Orthopaedic Centre }\end{array}$ \\
\hline Keywords: & $\begin{array}{l}\text { metal-on-metal hip replacement, follow-up, guidelines, revision surgery, } \\
\text { investigation }\end{array}$ \\
\hline
\end{tabular}




\section{Are the new MHRA follow-up recommendations for patients with metal-on-metal hip replacements justified?}

Gulraj Matharu and colleagues highlight that the new and more onerous MHRA follow-up recommendations for metal-on-metal hip replacement patients are still not evidence-based and will be extremely costly for health services to implement.

${ }^{1}$ Gulraj S Matharu - Clinical Research Fellow \& Orthopaedic Registrar

${ }^{1,2,3}$ Andrew Judge - Professor of Translational Statistics

${ }^{1,4}$ Hemant G Pandit * - Professor of Orthopaedic Surgery \& Consultant Orthopaedic Surgeon

${ }^{1}$ David W Murray * - Professor of Orthopaedic Surgery \& Consultant Orthopaedic Surgeon

* Denotes joint senior authorship

1 Nuffield Department of Orthopaedics, Rheumatology and Musculoskeletal Sciences, University of Oxford, Nuffield Orthopaedic Centre, Oxford, OX3 7LD, United Kingdom

${ }^{2}$ Bristol NIHR Biomedical Research Centre, Musculoskeletal Research Unit, University of Bristol, Southmead Hospital, Bristol, BS10 5NB, United Kingdom

${ }^{3}$ MRC Lifecourse Epidemiology Unit, University of Southampton, Southampton General Hospital, Southampton, SO16 6YD, United Kingdom

${ }^{4}$ Leeds Institute of Rheumatic and Musculoskeletal Medicine, University of Leeds, LS7 4SA, United Kingdom

Correspondence to: Gulraj S Matharu (gsm@doctors.org.uk)

Word count $=2509$ 


\section{Introduction}

Metal-on-metal hip replacements (MoMHRs) were commonly used in young active patients with arthritis. Approximately 1.5 million were implanted worldwide as stemmed hip replacements and hip resurfacings (non-stemmed surface replacements). ${ }^{1-3}$ These devices experienced high short-term failure rates. ${ }^{4,5}$ Many patients, including asymptomatic individuals, have undergone revision surgery for abnormal reactions to materials generated by the implants. This problem has collectively been termed adverse reactions to metal debris (ARMD). ${ }^{1,2,6}$ These poor outcomes were not predicted from pre-clinical testing. MoMHR is now rarely performed. ${ }^{1,2}$

Failure of conventional hip replacements is frequently related to symptomatic bone destruction, and revision surgery usually involves reconstruction with larger implants. Conversely MoMHRs failing due to ARMD are associated with bone and soft-tissue destruction (muscles, tendons, neuro-vasculature), with soft-tissue destruction often being unreconstructable, ${ }^{7,8}$ resulting in many patients doing poorly after revision procedures. ${ }^{8}$ Furthermore irreversible bone and soft-tissue damage can occur without marked symptoms, ${ }^{9}$ making screening MoMHR patients necessary. Therefore to identify and treat ARMD early, and hopefully improve subsequent outcomes for MoMHR patients, worldwide regulatory authorities recommend regular follow-up. ${ }^{10-14}$ Surveillance can include clinical review, blood metal ion levels (surrogate marker of implant wear), hip x-ray, and cross-sectional imaging (ultrasound and MRI). However the follow-up recommendations issued by authorities (UK, USA, Europe, Australia, and Canada) are extremely variable, not evidence-based, and very costly. $^{15}$ 
In June 2017, the Medicines and Healthcare products Regulatory Agency (MHRA) issued a planned update of their 2012 follow-up advice for all MoMHR patients. ${ }^{10,16}$ These new recommendations, endorsed by professional orthopaedic bodies, ${ }^{17}$ advise more intensive patient follow-up with most now requiring annual investigations for the implant lifetime. ${ }^{16}$ This will affect over 60,000 patients in the $\mathrm{UK}^{2}$, and many countries that also follow MHRA recommendations. Importantly most patients are asymptomatic with well-functioning MoMHRs. $^{18}$

Although problems have occurred with other implants (breast implants and pelvic meshes) ${ }^{19}$ the substantial increase in surveillance in MoMHR patients is on an unprecedented scale. Furthermore, considerable interest exists regarding the potential long-term systemic effects of MoMHRs due to high metal ion exposure, including the development of cancer. ${ }^{20}$ Systemic symptoms are broad but extremely rare. To assist detection of symptoms by clinicians these can be grouped into neurological (hearing and visual impairment/loss, peripheral neuropathy, cognitive impairment), cardiovascular (cardiomyopathy, breathlessness), and endocrine (hypothyroidism, fatigue, malaise, depression). ${ }^{21-24}$. Symptoms often resolve after revision surgery. Currently many large cohort studies report that MoMHR patients are not at increased risk of cancer, heart failure, or mortality compared with non-MoMHR patients. ${ }^{25-30}$. Evidence actually suggests that hip resurfacing patients have lower mortality rates compared with nonMoMHR patients. ${ }^{28,29}$

Despite the MHRA issuing a planned update, hospitals were not adequately forewarned before publication. Furthermore, professional bodies have recommended that concerned patients should contact their hospital or GP. ${ }^{17,31}$ Coupled with the misguided mass media 
coverage suggesting these devices are "toxic" and cause systemic problems, ${ }^{32-34}$ hospitals and GPs have been inundated with concerned patients. However these healthcare professionals cannot provide understandably anxious patients with information about the implications of the new guidance until clinical and management staff develop strategies for implementing the guidance. ${ }^{35}$ The lack of forewarning of the new MHRA guidance will therefore have already wasted valuable healthcare resources.

We consider the latest MHRA recommendations for MoMHR patients given the available evidence, and also assess the financial implications and potential impact on patients.

\section{What have the MHRA changed?}

The 2012 MHRA guidance recommended all patients with recalled implants, and symptomatic patients with non-recalled MoMHRs were reviewed annually with metal ions and cross-sectional imaging (ultrasound or MRI). ${ }^{10}$ The 2017 guidance still recommends that all symptomatic patients require annual follow-up, but now recommends that only some patients need cross-sectional imaging.

Asymptomatic hip resurfacing patients (approximately 30,000 UK patients) ${ }^{15,36}$ could previously be followed according to local protocol. ${ }^{10}$ Many hospitals discharged such patients either immediately or if initial reviews were satisfactory. Conversely, the 2017 guidance now considers all females with hip resurfacings and males with small resurfacing implants (femoral head $\leq 48 \mathrm{~mm}$ ) as high-risk. These asymptomatic patients now require more intensive annual follow-up. The remaining asymptomatic low-risk patients (males with hip resurfacing femoral heads $>48 \mathrm{~mm}$, and all stemmed hip replacements with femoral heads 
$<36 \mathrm{~mm}$ ) now require regular x-rays, metal ions, and Oxford Hip Scores (OHS) rather than follow-up as per local protocol. ${ }^{37-39}$

\section{Which MHRA changes are supported by evidence?}

The MHRA have made some positive changes to their recommendations, which are supported by the evidence-base. More comprehensive risk stratification for hip resurfacing patients is now included. All females, and males with small implants have achieved poor results with resurfacing. ${ }^{2,18}$ These individuals are now considered high-risk and require more intensive surveillance, regardless of symptoms. Implants with an established track-record in males, like the Birmingham Hip Resurfacing (BHR), ${ }^{2,18,40}$ now require less regular surveillance.

Universal blood testing, now recommended by the MHRA, is also favourable given recent large studies have developed and validated metal ion thresholds which effectively identify patients with unilateral and bilateral MoMHRs who are at low-risk of ARMD. ${ }^{41-43}$ Using OHSs to monitor patient pain and function has been suggested, ${ }^{15}$ with the MHRA now recommending universal OHSs. The OHS can detect sub-optimally functioning MoMHRs, even in asymptomatic patients. ${ }^{44,45}$

\section{Which MHRA changes are not supported by evidence?}

Some 2017 MHRA recommendations are not supported by evidence.

\section{- Evidence: All symptomatic patients require comprehensive investigation}

All worldwide authorities, including the 2012 MHRA guidance, recommend symptomatic patients undergo comprehensive testing with ions and cross-sectional imaging. ${ }^{15}$ This is 
because most patients with ARMD have pain, with symptoms potentially signifying bone and soft-tissue destruction which requires timely assessment and treatment to achieve good outcomes ${ }^{\mathbf{8 , 1 8 , 4 6}}$. The 2017 MHRA guidance still recommend ions and crosssectional imaging for symptomatic low-risk patients (e.g. male BHRs). However these recommendations have counter-intuitively been downgraded in symptomatic high-risk patients (e.g. females with recalled implants). High-risk symptomatic patients now only require cross-sectional imaging if metal ions are abnormal. The implications of not comprehensively investigating symptomatic high-risk patients are significant, including delayed diagnosis and treatment, poorer outcomes, and increased litigation.

- Evidence: Metal ions of $\geq 7$ parts per billion (ppb) cannot diagnose ARMD

The MHRA still recommend that patients with metal ions of $\geq 7 \mathrm{ppb}$ require closer surveillance, based on early weak data. ${ }^{47,48}$ Numerous studies demonstrate that metal ions are not useful for diagnosing ARMD, ${ }^{41-43,49,50}$ so continuing to promote this ion threshold for identifying patients who are potentially at risk of having ARMD is not advisable. However recent studies show that much lower ion levels (from 2-5.5 ppb) are very effective at identifying patients at low-risk of ARMD, ${ }^{41-43}$ therefore using these newer thresholds instead would help reassure many patients who do not have ARMD.

- Evidence: Longitudinal studies suggest most hip resurfacing patients with normal tests do not need annual surveillance

Metal ions show little variation in hip resurfacing patients when repeated within the mediumterm, even in high-risk patients. ${ }^{51-54}$ Similarly patients with normal cross-sectional imaging experience few changes when it is repeated early, ${ }^{55,56}$ with any problems occurring after several years. ${ }^{57}$ A longitudinal study of asymptomatic hip resurfacings demonstrated that no 
patient with normal initial tests (metal ions $<\mathbf{2}$ ppb and normal ultrasound scans) developed ARMD within five-years. ${ }^{44}$ This provides good evidence that this large subgroup of asymptomatic patients do not need repeat follow-up within five-years, which will result in considerable savings. However this is contradictory to the new MHRA guidance recommending annual follow-up for many such patients.

\section{$\underline{\text { Registry data does not support the new MHRA guidance }}$}

The MHRA were concerned that UK National Joint Registry (NJR) data (the world's largest arthroplasty registry) continued to show a risk of ARMD. ${ }^{16,17}$ However there will always be a risk of ARMD until all MoMHRs are removed. ${ }^{18}$ Importantly we are unaware of any new registry evidence suggesting the problem is getting significantly worse, especially in resurfacings. ${ }^{16}$ For all hip resurfacings, NJR revision rates for the MHRA guidance in 2017 $(12 \text {-years }=13.6 \%)^{2}$ and $2012(8$-years $=9.1 \%)$ were comparable with an average $1.1 \%$ annual rate. ${ }^{58}$ The Australian Registry reports similar findings. ${ }^{1}$ Furthermore the annual number of MoMHR revisions for all-causes and for ARMD has continued to decrease since 2012..$^{59,60}$ Therefore it is unclear how NJR data supports the increased MHRA surveillance.

Conversely, data from the NJR and others have demonstrated clinical benefits since implementing the 2012 MHRA guidance. ${ }^{10}$ Increased awareness of MoMHR problems and regular surveillance has led surgeons to revise patients earlier and for less severe abnormalities than previously. ${ }^{18}$ This has subsequently improved outcomes for patients following revision surgery ${ }^{60-62}$ compared with initially poor outcomes. ${ }^{8}$ Given these observations and the limited evidence supporting the new MHRA proposal of increased surveillance, caution is warranted. A systematic review of 122 studies observed the prevalence of revision for ARMD was highly variable, even for similar implants, but was 
closely related to surveillance intensity. ${ }^{63}$ The variability in surveillance is likely related to the inconsistent way follow-up guidance has been interpreted by different hospitals and surgeons. ${ }^{15}$ Increased surveillance can therefore lead to over-diagnosis of problems that may never require revision and may put patients at unnecessary risks associated with revision procedures, especially given that abnormal reactions not requiring treatment occur in wellfunctioning conventional hip replacements. ${ }^{64,65}$ Universal prostate cancer screening has similarly caused over-diagnosis and treatment related complications. ${ }^{66}$

\section{What will the new MHRA guidance cost?}

Previous work reported that the 2012 MHRA guidance would cost $£ 8.2$ million annually to implement in the UK. ${ }^{15}$ Using the same methodology described previously, ${ }^{15}$ the cost for implementing the 2017 MHRA recommendations in all MoMHR patients in the UK would be approximately $£ 14.8$ million annually (€16.8 million $/ \$ 19.4$ million). This is an increase of $80 \%$ from using the 2012 guidance. Although costs would decrease subsequently given low-risk patients would require less regular surveillance, the overall more intensive follow-up for asymptomatic hip resurfacings using the 2017 guidance means it will always cost more than previously. The professional body statement that the 2017 guidance will result in "a slight increase in the number of patients recommended for surveillance" compared with 2012 is not accurate. ${ }^{17}$

The outlined figures only estimate costs for initial reviews and investigations. The true costs to health services will be much greater. Costs do not consider the logistics of organising extra clinics, the resources required to perform and interpret tests, and the further investigations needed if abnormalities are identified. To review 60,000 patients just once will take approximately 1,000 staffed clinic days. Concerned patients have been directed back to 
GPs, ${ }^{17,31}$ but this will waste further precious resources until GPs have instructions from hospitals on how to advise patients. Importantly GPs often do not know which hip replacement patients receive (MoMHR or conventional), and they should not be asked to measure metal ions given samples are analysed at specialist laboratories with the results requiring careful interpretation. Many MoMHRs were performed privately and it is suspected in the UK these follow-up costs will fall on the NHS. Finally the cost of revision surgery is significant with $500-1,000$ MoMHR revisions performed annually in the UK (equates to $£ 5$-£10 million/year). ${ }^{60}$ This will be compounded further by the NHS revision procedure tariff recently being reduced by nearly $£ 3,000$, which will have financial implications for hospitals performing these revisions. ${ }^{67}$

\section{What do patients think about regular follow-up?}

Discussions with a group of patients with MoMHRs are summarised (Table 1). All patients felt reassured they were having annual or two-yearly clinical reviews, $x-$ rays, metal ion tests, and in some cases cross-sectional imaging. Although no patient had any serious concerns about potentially being over investigated, some patients would prefer to have less regular reviews and tests in the future given there was now some evidence supporting this approach.

Table 1: The perspective of metal-on-metal hip replacement patients regarding regular clinical surveillance and tests

\begin{tabular}{|l|l|}
\hline Details of & $-\mathrm{We}$ had discussions with five patients with metal-on-metal hip \\
patients & replacements, with these procedures performed at one of two centres in the \\
participating & UK. \\
& $\begin{array}{l}\text { - All patients questioned were asymptomatic and were having some type of } \\
\end{array}$
\end{tabular}




\begin{tabular}{|c|c|}
\hline & $\begin{array}{l}\text { hospital follow-up every } 1 \text { to } 2 \text { years. } \\
\text { - Age range }=55 \text { to } 76 \text { years. } \\
\text { - Gender }=3 \text { female and } 2 \text { male. } \\
\text { - Implants }=6 \text { hip resurfacings and } 1 \text { stemmed total hip replacement (as } 2 \\
\text { patients had bilateral implants). } \\
\text { - Surgeries were performed between } 6 \text { and } 10 \text { years ago on the NHS. }\end{array}$ \\
\hline $\begin{array}{l}\text { Patients } \\
\text { perspective } \\
\text { on regular } \\
\text { reviews and }\end{array}$ & $\begin{array}{l}\text { - All patients felt reassured that they were having regular clinical reviews, x- } \\
\text { rays, metal ion tests, and in some cases cross-sectional imaging. } \\
\text { - Patients felt these regular check-ups and tests provided them with security } \\
\text { of being followed up despite being pain free, and would allow any issues to } \\
\text { be identified early. } \\
\text { - No patient was concerned about the time they would need to take to travel } \\
\text { and attend these regular appointments. } \\
\text { - One patient highlighted their data may benefit others in the future by } \\
\text { contributing to research. } \\
\text { - Patients did not feel they were being over investigated, though some } \\
\text { recognised their views may have been different if the tests being performed } \\
\text { were more invasive (e.g. biopsies) or associated with more significant } \\
\text { (i.e. "Someone else can have my appointment if I do not actually need it."). } \\
\text { complications. } \\
\text { - Some patients would prefer to have less regular reviews and tests in the }\end{array}$ \\
\hline & plants, the tollow-up \\
\hline
\end{tabular}




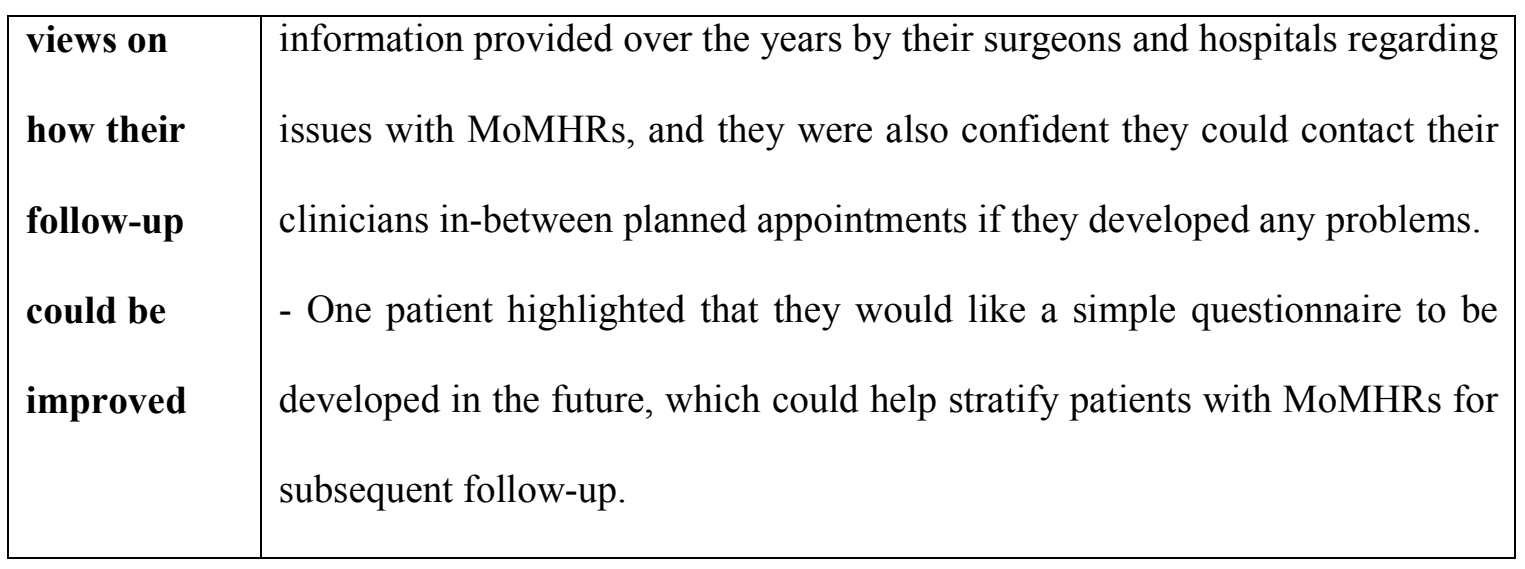

\section{Device regulation: protecting patients from poorly performing implants}

It is important the medical community learn lessons from failed MoMHRs. The introduction of new technologies must be rigorous and transparent. This should include usage by small expert groups, in randomised trials and independently controlled surveillance programmes. Any device concerns must be reported to manufacturers and regulators early, and must be taken seriously to minimise any potential patient harm. The initial device experience should be interpreted in combination with registry and other data before any widespread introduction of the device. Newer organisations (e.g. Beyond Compliance and the Orthopaedic Data Evaluation Panel) comprise independent panels of experts, which aim to safely introduce and monitor the performance of new implants in clinical practice. ${ }^{68,69}$

The encouraging early results of the first hip resurfacing (BHR) were incorrectly extrapolated to apply to other MoMHR designs. These devices were subsequently widely marketed and implanted without robust evidence about their safety and effectiveness, which ultimately placed huge numbers of patients at unnecessary risk. Adopting the more rigorous approaches described when using newer medical devices 
would have at least reduced the scale of the problems seen over the last decade with MoMHRs and other medical devices (e.g. breast implants and transvaginal meshes). ${ }^{19,70}$ However unlike breast implants and transvaginal meshes, the high MoMHR failure rates have resulted in this entire class of implants now being rarely used worldwide. Furthermore many MoMHR patients will be subjected to regular reviews and testing for the implant lifetime, which means the burden of this problem for both patients and hospitals will continue for many years to come.

\section{Conclusions}

The 2017 MHRA follow-up recommendations for MoMHR patients are more intensive than previously, especially for asymptomatic hip resurfacing patients, with every patient now requiring tests. The professional bodies support the update, and consider the more regular review of low-risk patients "a precautionary measure to reduce the small risk of complications". ${ }^{17}$ It is acknowledged that some improvements have been made with the new guidance in-line with evidence. However the registry data supporting increased surveillance is unclear, and it is highly likely that the substantial increase in follow-up costs will not be offset by detecting the small proportion of asymptomatic hip resurfacing patients with ARMD requiring revision that would otherwise have been missed. Furthermore evidence now suggests that asymptomatic hip resurfacing patients with normal initial tests can be reassured and reviewed in five-years. ${ }^{44}$ This would reduce any unnecessary anxieties and concerns in many asymptomatic patients with well-functioning implants who now need regular follow-up. However it is recognised that the patients spoken to did not have any serious objections about potentially being over investigated. Medico-legal pressures caused worldwide authorities to recommend regular surveillance due to a lack of evidence. ${ }^{15}$ However evidence now supports less regular surveillance in many patients, which would 
allow better use of healthcare resources and also afford some protection from litigation. If the new MHRA guidance becomes mandatory the financial burden will be enormous. Given the known pressures within health services it will inevitably not be sustainable, even short-term. It remains to be seen whether implant manufacturers will contribute to some, or all, of the extra costs. ${ }^{71}$

Two key areas for future research are: (1) longitudinal studies with extended follow-up to assess how tests in MoMHR patients change over time, and also to establish whether these implants pose any significant systemic problems, and (2) assessments of cohorts of MoMHR patients who have undergone revision surgery to establish which clinical, laboratory, and cross-sectional imaging findings predict patients with aggressive ARMD requiring revision, and also to determine how frequently these patients should be seen after revision and what tests are needed. Answering these important clinical questions will continue to improve how we manage MoMHR patients. 


\section{$\underline{\text { Box 1: Key messages }}$}

- The MHRA has updated their 2012 follow-up advice, and now recommends more intensive follow-up for all MoMHR patients. Most patients now require annual investigations (universal blood metal ions and patient reported outcome measures) for the implant lifetime.

- This will affect over 60,000 patients in the UK with these implants, as well as many countries worldwide that follow MHRA advice.

- The guidance does not reflect current evidence. There are inconsistencies in how to investigate symptomatic patients, and there is no recognition that many asymptomatic hip resurfacing patients with normal tests do not require annual follow-up.

- The cost to health services for implementing the new MHRA guidance is substantial at an estimated $£ 14.8$ million annually ( $80 \%$ increase on previous costs). This does not include the resources required to perform extra reviews and tests, and it remains unclear whether implant manufacturers will contribute to these extra costs. 


\section{References}

1. AOANJRR. Australian Orthopaedic Association National Joint Replacement Registry (AOANJRR) Hip, Knee \& Shoulder Arthroplasty Annual Report. 2016:https://aoanjrr.sahmri.com/annual-reports-2016.

2. NJR. National Joint Registry (NJR) for England, Wales, Northern Ireland and the Isle of Man 13th Annual Report. 2016:http://www.njrcentre.org.uk/njrcentre/Portals/0/Documents/England/Reports/13th Annual Report/07950\%07920NJR\%07920Annual\%07920Report $2016 \quad$ 2020ONLINE 2020REPORT.pdf.

3. Bozic KJ, Kurtz S, Lau E, Ong K, Chiu V, Vail TP, Rubash HE, Berry DJ. The epidemiology of bearing surface usage in total hip arthroplasty in the United States. $J$ Bone Joint Surg Am. 2009;91(7):1614-1620.

4. Smith AJ, Dieppe P, Howard PW, Blom AW, National Joint Registry for E, Wales. Failure rates of metal-on-metal hip resurfacings: analysis of data from the National Joint Registry for England and Wales. Lancet. 2012;380(9855):1759-1766.

5. Smith AJ, Dieppe P, Vernon K, Porter M, Blom AW, National Joint Registry of E, Wales. Failure rates of stemmed metal-on-metal hip replacements: analysis of data from the National Joint Registry of England and Wales. Lancet. 2012;379(9822):1199-1204.

6. Langton DJ, Jameson SS, Joyce TJ, Hallab NJ, Natu S, Nargol AV. Early failure of metal-on-metal bearings in hip resurfacing and large-diameter total hip replacement: A consequence of excess wear. J Bone Joint Surg Br. 2010;92(1):38-46.

7. Liddle AD, Satchithananda K, Henckel J, Sabah SA, Vipulendran KV, Lewis A, Skinner JA, Mitchell AW, Hart AJ. Revision of metal-on-metal hip arthroplasty in a tertiary center: a prospective study of 39 hips with between 1 and 4 years of follow-up. Acta Orthop. 2013;84(3):237-245. 
8. Grammatopoulos G, Pandit H, Kwon YM, Gundle R, McLardy-Smith P, Beard DJ, Murray DW, Gill HS. Hip resurfacings revised for inflammatory pseudotumour have a poor outcome. J Bone Joint Surg Br. 2009;91(8):1019-1024.

9. Almousa SA, Greidanus NV, Masri BA, Duncan CP, Garbuz DS. The natural history of inflammatory pseudotumors in asymptomatic patients after metal-on-metal hip arthroplasty. Clin Orthop Relat Res. 2013;471(12):3814-3821.

10. MHRA. Medicines \& Healthcare products Regulatory Agency (MHRA). Medical Device Alert: all metal-on-metal (MoM) hip replacements. MDA/2012/036. 2012:http://www.mhra.gov.uk/.

11. Therapeutic Goods Administration DoH, Australian Government. Metal-on-metal hip replacement implants — information for general practitioners, orthopaedic surgeons and other health professionals. 2012:http:/www.tga.gov.au/hp/information-devices-mom-hipimplants.htm.

12. FDA. U.S. Food and Drug Administration (FDA). Medical Devices. Metal-on-Metal Hip Implants. Information for Orthopaedic Surgeons. 2013:http://www.fda.gov/MedicalDevices/ProductsandMedicalProcedures/ImplantsandProst hetics/MetalonMetalHipImplants/ucm241667.htm.

13. Hannemann F, Hartmann A, Schmitt J, Lutzner J, Seidler A, Campbell P, Delaunay CP, Drexler H, Ettema HB, Garcia-Cimbrelo E, Huberti H, Knahr K, Kunze J, Langton DJ, Lauer W, Learmonth I, Lohmann CH, Morlock M, Wimmer MA, Zagra L, Gunther KP. European multidisciplinary consensus statement on the use and monitoring of metal-on-metal bearings for total hip replacement and hip resurfacing. Orthop Traumatol Surg Res. 2013;99(3):263-271. 
14. Canada. Health Canada. Metal-on-Metal Hip Implants - Information for Orthopaedic Surgeons Regarding Patient Management Following Surgery - For Health Professionals. 2012:http://healthycanadians.gc.ca/recall-alert-rappel-avis/hc-sc/2012/15835a-eng.php.

15. Matharu GS, Mellon SJ, Murray DW, Pandit HG. Follow-Up of Metal-on-Metal Hip Arthroplasty Patients Is Currently Not Evidence Based or Cost Effective. J Arthroplasty. 2015;30(8):1317-1323.

16. MHRA. Medical device alert: MDA/2017/018: all metal-on-metal (MoM) hip replacements - updated advice for follow-up of patients. 29th June 2017:https://www.gov.uk/drug-device-alerts/all-metal-on-metal-mom-hip-replacementsupdated-advice-for-follow-up-of-patients.

17. BOA/BHS joint statement: MoM hip implants - update from the Medicines and Healthcare products Regulatory Agency (MHRA). 30th June 2017:https://www.boa.ac.uk/latest-news/boabhs-joint-statement-mom-hip-implants-updatefrom-the-the-medicines-and-healthcare-products-regulatory-agency-mhra/.

18. Matharu GS, Judge A, Murray DW, Pandit HG. Prevalence of and Risk Factors for Hip Resurfacing Revision: A Cohort Study Into the Second Decade After the Operation. $J$ Bone Joint Surg Am. 2016;98(17):1444-1452.

19. Cohen D. Medical devices face tougher premarket testing under new EU laws. $B M J$. 2017;357:j1870.

20. Keegan GM, Learmonth ID, Case CP. Orthopaedic metals and their potential toxicity in the arthroplasty patient: A review of current knowledge and future strategies. J Bone Joint Surg Br. 2007;89(5):567-573.

21. Zywiel MG, Cherian JJ, Banerjee S, Cheung AC, Wong F, Butany J, Gilbert C, Overgaard C, Syed K, Jacobs JJ, Mont MA. Systemic cobalt toxicity from total hip 
arthroplasties: review of a rare condition Part 2. measurement, risk factors, and step-wise approach to treatment. Bone Joint J. 2016;98-B(1):14-20.

22. Cheung AC, Banerjee S, Cherian JJ, Wong F, Butany J, Gilbert C, Overgaard C, Syed K, Zywiel MG, Jacobs JJ, Mont MA. Systemic cobalt toxicity from total hip arthroplasties: review of a rare condition Part 1 - history, mechanism, measurements, and pathophysiology. Bone Joint J. 2016;98-B(1):6-13.

23. Tower SS. Arthroprosthetic cobaltism: neurological and cardiac manifestations in two patients with metal-on-metal arthroplasty: a case report. $J$ Bone Joint Surg Am. 2010;92(17):2847-2851.

24. Bradberry SM, Wilkinson JM, Ferner RE. Systemic toxicity related to metal hip prostheses. Clin Toxicol (Phila). 2014;52(8):837-847.

25. Smith AJ, Dieppe P, Porter M, Blom AW, National Joint Registry of E, Wales. Risk of cancer in first seven years after metal-on-metal hip replacement compared with other bearings and general population: linkage study between the National Joint Registry of England and Wales and hospital episode statistics. BMJ. 2012;344:e2383.

26. Makela KT, Visuri T, Pulkkinen P, Eskelinen A, Remes V, Virolainen P, Junnila M, Pukkala E. Risk of cancer with metal-on-metal hip replacements: population based study. BMJ. 2012;345:e4646.

27. Makela KT, Visuri T, Pulkkinen P, Eskelinen A, Remes V, Virolainen P, Junnila M, Pukkala E. Cancer incidence and cause-specific mortality in patients with metal-on-metal hip replacements in Finland. Acta Orthop. 2014;85(1):32-38.

28. McMinn DJ, Snell KI, Daniel J, Treacy RB, Pynsent PB, Riley RD. Mortality and implant revision rates of hip arthroplasty in patients with osteoarthritis: registry based cohort study. BMJ. 2012;344:e3319. 
29. Kendal AR, Prieto-Alhambra D, Arden NK, Carr A, Judge A. Mortality rates at 10 years after metal-on-metal hip resurfacing compared with total hip replacement in England: retrospective cohort analysis of hospital episode statistics. BMJ. 2013;347:f6549.

30. Berber R, Abdel-Gadir A, Rosmini S, Captur G, Nordin S, Culotta V, Palla L, Kellman P, Lloyd GW, Skinner JA, Moon JC, Manisty C, Hart AJ. Assessing for Cardiotoxicity from Metal-on-Metal Hip Implants with Advanced Multimodality Imaging Techniques. J Bone Joint Surg Am. 2017;99(21):1827-1835.

31. National Health Service. Hip replacement - metal-on-metal implant advice. 2017:http://www.nhs.uk/Conditions/Hip-replacement/Pages/Metal-on-metalimplants.aspx.

32. More than 50,000 Britons with 'metal on metal' hips told to have X-rays and blood tests over toxic fears The Telegraph. 29th June 2017:http://www.telegraph.co.uk/news/2017/2006/2029/50000-britons-metal-metal-hipsface-X-rays-blood-tests-toxic/.

33. 'Metal-on-metal' hip implant patients recalled for tests over toxicity fears. The Guardian. 29th June 2017:https://www.theguardian.com/science/2017/jun/2029/metal-onmetal-hip-implant-patients-recalled-for-tests-over-toxicity-fears - img-2011.

34. Metal hip replacement patients recalled for tests. The Times. 30th June 2017:https://www.thetimes.co.uk/article/metal-hip-replacement-patients-recalled-for-testshsrf9hs25.

35. Matharu VK, Matharu GS. Metal-on-metal hip replacements: implications for general practice. Br J Gen Pract. 2017;67(665):544-545.

36. Hart AJ, Sabah SA, Sampson B, Skinner JA, Powell JJ, Palla L, Pajamaki KJ, Puolakka T, Reito A, Eskelinen A. Surveillance of Patients with Metal-on-Metal Hip Resurfacing and Total Hip Prostheses: A Prospective Cohort Study to Investigate the 
Relationship Between Blood Metal Ion Levels and Implant Failure. J Bone Joint Surg Am. 2014;96(13):1091-1099.

37. Roth NS, Campbell PT, Caron MG, Lefkowitz RJ, Lohse MJ. Comparative rates of desensitization of beta-adrenergic receptors by the beta-adrenergic receptor kinase and the cyclic AMP-dependent protein kinase. Proc Natl Acad Sci U S A. 1991;88(14):6201-6204.

38. Dawson J, Fitzpatrick R, Carr A, Murray D. Questionnaire on the perceptions of patients about total hip replacement. J Bone Joint Surg Br. 1996;78(2):185-190.

39. Murray DW, Fitzpatrick R, Rogers K, Pandit H, Beard DJ, Carr AJ, Dawson J. The use of the Oxford hip and knee scores. J Bone Joint Surg Br. 2007;89(8):1010-1014.

40. Matharu GS, McBryde CW, Pynsent WB, Pynsent PB, Treacy RB. The outcome of the Birmingham Hip Resurfacing in patients aged $<50$ years up to 14 years post-operatively. Bone Joint J. 2013;95-B(9):1172-1177.

41. Matharu GS, Berryman F, Brash L, Pynsent PB, Dunlop DJ, Treacy RB. Can blood metal ion levels be used to identify patients with bilateral Birmingham Hip Resurfacings who are at risk of adverse reactions to metal debris? Bone Joint J. 2016;98-B(11):1455-1462.

42. Matharu GS, Berryman F, Brash L, Pynsent PB, Treacy RB, Dunlop DJ. The Effectiveness of Blood Metal Ions in Identifying Patients with Unilateral Birmingham Hip Resurfacing and Corail-Pinnacle Metal-on-Metal Hip Implants at Risk of Adverse Reactions to Metal Debris. J Bone Joint Surg Am. 2016;98(8):617-626.

43. Matharu GS, Berryman F, Judge A, Reito A, McConnell J, Lainiala O, Young S, Eskelinen A, Pandit HG, Murray DW. Blood metal ion thresholds to identify patients with metal-on-metal hip implants at risk of adverse reactions to metal debris: an external multicenter validation study of Birmingham Hip Resurfacing and Corail-Pinnacle implants. $J$ Bone Joint Surg Am. 2017;99(In Press - accepted 21st April 2017). 
44. Low AK, Matharu GS, Ostlere SJ, Murray DW, Pandit HG. How Should We FollowUp Asymptomatic Metal-on-Metal Hip Resurfacing Patients? A Prospective Longitudinal Cohort Study. J Arthroplasty. 2016;31(1):146-151.

45. Matharu GS, Ostlere SJ, Pandit HG, Murray DW. What is the natural history of asymptomatic pseudotumours in metal-on-metal hip resurfacing patients? Hip Int. 2016;26(6):522-530.

46. Kwon YM, Lombardi AV, Jacobs JJ, Fehring TK, Lewis CG, Cabanela ME. Risk stratification algorithm for management of patients with metal-on-metal hip arthroplasty: consensus statement of the American Association of Hip and Knee Surgeons, the American Academy of Orthopaedic Surgeons, and the Hip Society. J Bone Joint Surg Am. 2014;96(1):e4.

47. Hart AJ, Sabah S, Henckel J, Lewis A, Cobb J, Sampson B, Mitchell A, Skinner JA. The painful metal-on-metal hip resurfacing. J Bone Joint Surg Br. 2009;91(6):738-744.

48. MHRA. Medical device alert: ASR hip replacement implant manufactured by DePuy International Ltd. 2010:http:// www.mhra.gov.uk.

49. Hart AJ, Sabah SA, Bandi AS, Maggiore P, Tarassoli P, Sampson B, J AS. Sensitivity and specificity of blood cobalt and chromium metal ions for predicting failure of metal-onmetal hip replacement. J Bone Joint Surg Br. 2011;93(10):1308-1313.

50. Van Der Straeten C, Grammatopoulos G, Gill HS, Calistri A, Campbell P, De Smet KA. The 2012 Otto Aufranc Award: The interpretation of metal ion levels in unilateral and bilateral hip resurfacing. Clin Orthop Relat Res. 2013;471(2):377-385.

51. Langton DJ, Sidaginamale RP, Joyce TJ, Natu S, Blain P, Jefferson RD, Rushton S, Nargol AV. The clinical implications of elevated blood metal ion concentrations in asymptomatic patients with MoM hip resurfacings: a cohort study. BMJ Open. 2013;3(3). 
52. Van Der Straeten C, Van Quickenborne D, De Roest B, Calistri A, Victor J, De Smet K. Metal ion levels from well-functioning Birmingham Hip Resurfacings decline significantly at ten years. Bone Joint J. 2013;95-B(10):1332-1338.

53. Reito A, Lainiala O, Nieminen J, Eskelinen A. Repeated metal ion measurement in patients with bilateral metal on metal (ASR) hip replacements. Orthop Traumatol Surg Res. 2016;102(2):167-173.

54. Reito A, Moilanen T, Puolakka T, Pajamaki J, Eskelinen A. Repeated metal ion measurements in patients with high risk metal-on-metal hip replacement. Int Orthop. 2014;38(7):1353-1361.

55. van der Weegen W, Brakel K, Horn RJ, Hoekstra HJ, Sijbesma T, Pilot P, Nelissen RG. Asymptomatic pseudotumours after metal-on-metal hip resurfacing show little change within one year. Bone Joint J. 2013;95-B(12):1626-1631.

56. Reito A, Elo P, Puolakka T, Pajamaki J, Nieminen J, Eskelinen A. Repeated magnetic resonance imaging in 154 hips with large-diameter metal-on-metal hip replacement. Acta Orthop. 2014;85(6):570-576.

57. Ebreo D, Bell PJ, Arshad H, Donell ST, Toms A, Nolan JF. Serial magnetic resonance imaging of metal-on-metal total hip replacements. Follow-up of a cohort of $28 \mathrm{~mm}$ Ultima TPS THRs. Bone Joint J. 2013;95-B(8):1035-1039.

58. NJR. National Joint Registry (NJR) for England, Wales, Northern Ireland and the Isle of Man 9th Annual Report. 2012:http://www.njrcentre.org.uk/njrcentre/Portals/0/Documents/England/Reports/9th_annua 1_report/NJR 9th\%220Annual\%220Report 2012.pdf.

59. Matharu GS, Pandit HG, Murray DW, Judge A. Adverse reactions to metal debris occur with all types of hip replacement not just metal-on-metal hips: a retrospective observational study of 3340 revisions for adverse reactions to metal debris from the National 
Joint Registry for England, Wales, Northern Ireland and the Isle of Man. BMC Musculoskelet Disord. 2016;17(1):495.

60. Matharu GS, Judge A, Murray DW, Pandit HG. Outcomes after metal-on-metal hip revision surgery depend on the reason for failure: a propensity score matched study. Clin Orthop Relat Res. 2017(In Press - accepted on 9th June 2017).

61. Matharu GS, Judge A, Pandit HG, Murray DW. Which factors influence the rate of failure following metal-on-metal hip arthroplasty revision surgery performed for adverse reactions to metal debris? An analysis from the National Joint Registry for England and Wales. Bone Joint J. 2017;99-B(8):1020-1027.

62. De Smet KA, Van Der Straeten C, Van Orsouw M, Doubi R, Backers K, Grammatopoulos G. Revisions of metal-on-metal hip resurfacing: lessons learned and improved outcome. Orthop Clin North Am. 2011;42(2):259-269, ix.

63. Reito A, Lainiala O, Elo P, Eskelinen A. Prevalence of Failure due to Adverse Reaction to Metal Debris in Modern, Medium and Large Diameter Metal-on-Metal Hip Replacements--The Effect of Novel Screening Methods: Systematic Review and Metaregression Analysis. PLoS One. 2016;11(3):e0147872.

64. Bisseling P, de Wit BW, Hol AM, van Gorp MJ, van Kampen A, van Susante JL. Similar incidence of periprosthetic fluid collections after ceramic-on-polyethylene total hip arthroplasties and metal-on-metal resurfacing arthroplasties: results of a screening metal artefact reduction sequence-MRI study. Bone Joint J. 2015;97-B(9):1175-1182.

65. van der Veen HC, Reininga IH, Zijlstra WP, Boomsma MF, Bulstra SK, van Raay JJ. Pseudotumour incidence, cobalt levels and clinical outcome after large head metal-on-metal and conventional metal-on-polyethylene total hip arthroplasty: mid-term results of a randomised controlled trial. Bone Joint J. 2015;97-B(11):1481-1487. 
66. Hoffman RM. Clinical practice. Screening for prostate cancer. $N$ Engl J Med. 2011;365(21):2013-2019.

67. Cohen D. All patients with metal-on-metal hip implants should undergo tests, says MHRA. BMJ. 2017;358:j3246.

68. Beyond Compliance. http://www.beyondcompliance.org.uk.

69. Orthopaedic Data Evaluation Panel (ODEP). http://www.odep.org.uk.

70. Heneghan C, Aronson JK, Goldacre B, Mahtani KR, Pluddemann A, Onakpoya I. Transvaginal mesh failure: lessons for regulation of implantable devices. BMJ. 2017;359:j5515.

71. Carr A. Follow-up of patients with metal-on-metal hip replacements. BMJ. 2017;358:j3387. 


\section{Contributors and sources}

GSM (Orthopaedic Registrar and $\mathrm{PhD}$ student) proposed and developed this article, performed the analysis, conducted the patient interviews, and drafted and revised the manuscript. AJ (Professor of Translational Statistics) contributed to the development of this article, and revised the manuscript for important intellectual content. HGP and DWM (both are Professors of Orthopaedic Surgery and Consultant Orthopaedic Surgeons) contributed to the development of this article, and revised the manuscript for important intellectual content. All authors read and approved the final manuscript. DWM is the guarantor.

\section{Conflicts of interest}

We have read and understood the BMJ Group Policy on declaration of interests and declare the following interests: GSM has received financial support for other research work from Arthritis Research UK, The Orthopaedics Trust, The Royal College of Surgeons of England, and The Royal Orthopaedic Hospital Hip Research and Education Charitable Fund; AJ has received consultancy, lecture fees and honoraria from Servier, UK Renal Registry, Oxford Craniofacial Unit, IDIAP Jordi Gol, Freshfields Bruckhaus Deringer, is a member of the Data Safety and Monitoring Board (which involved receipt of fees) from Anthera Pharmaceuticals, INC., and received consortium research grants from ROCHE; HGP is a paid consultant for Kennedys Law and has received institutional research grants from UKIERI and NIHR; HGP and DWM are paid consultants and speakers for Zimmer-Biomet, and both receive institutional research funding from Zimmer-Biomet and Stryker; DWM receives royalties related to an Orthopaedic knee replacement manufactured by Zimmer-Biomet. 


\section{Licence}

The Corresponding Author has the right to grant on behalf of all authors and does grant on behalf of all authors, an exclusive licence (or non exclusive for government employees) on a worldwide basis to the BMJ Publishing Group Ltd ("BMJ"), and its Licensees to permit this article (if accepted) to be published in The $B M J^{\text {s }}$ editions and any other BMJ products and to exploit all subsidiary rights, as set out in our licence.

\section{Patient involvement}

Discussions were undertaken with a group of patients with metal-on-metal hip replacements to obtain their perspectives on various issues related to this article as described (Table 1). 